\title{
Reforming the Canadian Refugee Determination System
}

\author{
Martin Collacott
}

\begin{abstract}
If Canadian refugee policy is to serve interests of Canadians as well as those of genuine refugees in an effective manner, far more radical changes will be needed than have been attempted to date. They must include the introduction of robust safe third country designations, a review of the 1985 Singh decision of the Supreme Court of Canada, and possible withdrawal by Canada of its accession to the 1951 UN Refugee Convention. Other measures should also be considered such as placing an annual limit on the intake of refugees from overseas combined with that of successful incountry asylum seekers as well as establishing provision for temporary refugee status in Canada in addition to permanent resettlement. Measures should be taken to return Canada to its role primarily as a resettlement country for refugees selected abroad and not one that accommodates large numbers of asylum seekers making claims on our territory. With strong public backing for major changes, political parties that oppose such reforms will do so at the risk of losing electoral support.
\end{abstract}

\section{Résumé}

Si la politique envers les réfugiés au Canada doit servir les intérêts des Canadiens ainsi que ceux des réfugiés de bonne foi d'une manière efficace, des changements bien plus radicaux seront nécessaires que ceux qui ont été tentés jusqu'ici. Ces changements doivent comprendre l'introduction de désignations robustes de pays tiers sûrs, un examen de la décision Singh de la Cour suprême du Canada de 1985 et le retrait éventuel par le Canada de son adhésion à la Convention du 28 juillet 1951 relative au statut des réfugiés de l'ONU. D'autres mesures devraient également être considérées comme la mise en place d'un plafond annuel à l'accueil des réfugiés d'outre-mer combiné à l'acceptation de demandes d'asile sur le territoire ainsi que l'établissement de dispositions pour le statut de réfugié temporaire au Canada et la réinstallation permanente. Des mesures devraient être prises pour permettre au Canada de retrouver son rôle comme pays avant tout de réinstallation pour les réfugiés sélectionnés à l'étranger et non pas comme pays accueillant un grand nombre de demandeurs d'asile faisant des réclamations sur son territoire. Compte tenu de l'appui soutenu du public pour des changements majeurs, les partis politiques qui s'opposent à ces réformes le font au risque de perdre leur soutien électoral.

\section{Introduction}

The year 2010 saw major activity on the part of the Government of Canada in terms of presenting legislation designed to deal with perceived shortcomings of the refugee determination system. Early in the year a bill was tabled in Parliament to address sharp rises in refugee claims by nationals of countries that would not normally be considered as refugee-producing. In the years preceding the tabling of the bill there had been concern over the large number of claims by asylum seekers from the Czech Republic and Mexico. The case made by refugee claimants from Mexico was usually that they were fleeing violence precipitated by drug cartels, while the Czechs were from the Roma (Gypsy) minority and cited the widespread discrimination they encountered in their homeland.

While both groups of claimants had reason to believe they would be better off in Canada, the Government did not consider that the reasons they advanced in support of their applications for protection constituted convincing cases of persecution as required by the 1951 United Nations Convention relating to the Status of Refugees. With regard to Mexican claimants, fleeing criminal violence was not 
regarded as being equivalent to suffering from persecution as stipulated by the Convention, and if this kind of problem were accepted as grounds for being granted asylum, there were undoubtedly millions more around the world entitled to come here as refugees.

As for the Roma from the Czech Republic, suffering from discrimination was not considered equivalent to government persecution. It did not help their case that Roma from the Czech Republic were free to travel to any other member country of the European Union, none of which would consider a refugee claim from a Czech citizen.

An indication of the extent to which Canada was out of line with other countries in considering claims from the nationals of these two nations is that according to UNHCR statistics no other nation granted refugee status to a Czech in 2008 and only Canada and the United States did so in the case of Mexicans-with Canada accepting far more than the US. ${ }^{1}$

\section{Efforts to Make the Refugee Determination System More Efficient}

The Government accordingly tabled legislation designed to deal with large increases in arrivals of asylum seekers as well as measures to introduce more efficiency and fairness to what is widely regarded as a largely dysfunctional refugee determination system. The bill presented to Parliament was aimed at speeding up the processing and disposition of both applications that appeared to have little merit as well as those that were well-founded and stood a good chance of being approved.

A specific objective of the legislation was to deny the opportunity for in-Canada appeals to claimants from nonrefugee producing countries. The purpose of this was to avoid situations where such unsuccessful claimants could remain here while their appeals wound their way through the system and thereby increase their chances of remaining here indefinitely by one means or another. Other countries, such as the United Kingdom, require that appeals from such refused claimants be pursued from abroad if they wish to do so in order that they don't gain advantage from prolonging their stay in Britain.

Included in the legislation package was the creation of a Refugee Appeal Division (RAD) of the Immigration and Refugee Board (IRB), a unit that had been provided for in the 2001 Immigration and Refugee Protection Act (IRPA). Successive Liberal and Conservative immigration ministers had refused, however, to implement this section of the Act since in their estimation there were already too many opportunities for refugee claimants turned down by the IRB to have their cases appealed or reviewed. Until this was sorted out, it was viewed as unwise to add yet another level of appeal. ${ }^{2}$

In consequence, in the bill presented in early 2010, the Government included provision for the establishment of the RAD in combination with changes to the system that would consolidate the existing opportunities to have failed cases appealed and reviewed. If all the elements of the bill were approved, it was, therefore, expected to bring about an overall improvement of the system in terms of efficiency and timely disposition of claims.

In the event, however, refugee lawyers and activists as well as members of opposition parties in Parliament were successful in retaining inclusion of the RAD while diluting other parts of the legislation. It remains to be seen, in the circumstances, whether the Balanced Refuge Reform Act passed in June will be an improvement on the current system. Immigration expert James Bissett, for one, believes it likely that the provisions of the new legislation will create even more backlogs. ${ }^{3}$

\section{Arrival of the Sun Sea}

Later in 2010 the Government again tried to introduce reforms with the tabling of a bill designed to curb human smuggling following the arrival of a boatload of 492 Tamil asylum seekers in August on a vessel named the Sun Sea. While Canadian authorities had known for weeks that the Sun Sea was headed in this direction from Asia, the Government felt it had no choice but to allow it to land in Canada and permit those on board to claim refugee status. Its arrival raised questions about the extent to which we are able to control who enters our territory and, by implication, the degree to which we are able to protect our sovereignty.

\section{Public Opinion Supports Strong Measures to Prevent Human Smuggling}

Public opinion is clearly in support of taking a firm line on how we should deal with such incidents. A Leger Marketing poll ${ }^{4}$ released after the arrival of the Sun Sea found that 60 per cent of those surveyed thought the ship and its passengers should be turned away and escorted back to Sri Lanka by the Canadian Navy. According to an Angus Reid poll ${ }^{5}$ taken at about the same time, almost half of those surveyed felt that, even if the refugee claims of those who arrived on the Sun Sea were found to be legitimate and no links were made between them and any terrorist organization, the ship's crew and passengers should still be sent back to Sri Lanka. While it should not be concluded from this that Canadians are unsympathetic towards the plight of refugees in general, these survey results clearly reflect a high level of frustration on the part of Canadians with regard to what they perceive as abuse of the system. 
There is fairly broad agreement among political parties that the bill should provide heavy fines and sentences for those who organize the voyages as well as major penalties for the owners and operators of the ships involved. The sections being challenged by opposition parties in Parliament are those aimed at deterring asylum seekers themselves from using the services of human smugglers to get to Canada.

The bill if approved by Parliament would stipulate that asylum seekers who reach Canadian shores in such mass arrivals would be detained for up to a year in order to determine their identity, admissibility, and whether they were involved in illegal activity. They would, furthermore, be barred from applying for permanent resident status for five years even if they were granted refugee status, and would not be able to sponsor family members for five years. In addition they would lose their status if they went back for visits to the country from which they sought refuge or if the situation there improved to the point where it was safe for them to return.

Notwithstanding the strong indications noted above that public opinion supports a firm stance on refugee claimants using human smugglers to enter Canada, refugee advocates and opposition members in Parliament have taken the position that the asylum seekers should be considered as victims of the human smugglers. They should not be considered as complicit in a criminal operation given that they may have had no other means of reaching Canada to make a refugee claim. In the view of refugee advocates, the bill would, moreover, create a two-tier system in which asylum seekers arriving as part of a "designated human smuggling event" are treated unfairly in comparison with those who get here by others means and are, therefore, not subject to such harsh rules.

While there is some merit in the claim that asylum seekers using human smugglers to get here will be treated more sternly than those who don't, it is not unreasonable to ask whether some of the tougher rules should not be applied to refugee claimants in general. It is difficult to see, for example, why any asylum seeker should be able to pursue their claim if they have no problem with going back to visit the countries from which they said they had to flee. ${ }^{6}$ The Government, in fact, has the legal right to terminate its obligation not to refoule in such cases through "cessation"although it rarely applies this provision.

\section{Need to Establish Temporary Status for Refugees in Canada}

In like manner, there would seem to be good reason for requiring that all asylum seekers should be prepared to return to their countries of origin if the situation there improves within a reasonable period of time and they are no longer at risk if they go back. In 1999, for example, Canada along with other Western countries accepted thousands of Kosovars as refugees on the basis that they were considered in danger from Serbian armed forces in Kosovo. Later the same year an agreement was reached for the withdrawal of Serbian troops and the introduction of UN peacekeepers to maintain security and, in consequence, by June of 2000 more than 800,000 Kosovars who had gone to other countries to flee the violence had returned home.

Most Western countries encouraged those on their territory to do so and in some instances put pressure on them to this end. In the case of Australia, for example, 95 per cent of the 4,000 Kosovars who had been admitted as refugees returned home. Canada, however, has no provision for granting temporary status for refugees and a large majority of Kosovars in this country chose to stay ${ }^{7}$ - which should hardly come as a surprise considering the much better social services and economic prospects available to them here than in Kosovo.

In the circumstances, there is a strong case for creating temporary protection status for refugees fleeing from areas where the situation is evolving and may improve in the foreseeable future to the extent that they can safely return. Other countries have such provisions and there is no reason why Canada should not.

As for the proposed legislation, even if it were approved by Parliament without major changes, it would be unlikely to reduce substantially the very large number of individuals making refugee claims in Canada. Relatively few, in fact, reach our soil in mass arrivals such as we saw in the case of the Sun Sea; most come individually or in small numbers and usually by air.

In addition, some asylum seekers have no need to employ human smugglers to enter Canada. Actor Randy Quaid and his wife, for example, as American citizens were simply able to cross the border legally from the United States in order to be able to claim refugee status - which they said they required because they were in danger from Hollywood "star whackers" and had been persecuted by American authorities for the past twenty years.

\section{Canada Should Concentrate on Being a Country of Resettlement-Not of First Asylum}

This leads to the question of whether Canada simply makes it too easy to make a refugee claim on our territory. In this respect, it is useful to recall that when Canada began accepting refugees in the wake of World War II it did not see itself as a country of first asylum but rather as one that could make a contribution by resettling those who had sought refuge in other countries. Accordingly, we took in 186,000 displaced persons from Europe in the years following the 
war as well as significant numbers after the Hungarian revolution in 1956 and the uprising in Czechoslovakia in 1968. We continued with this tradition in the case of Asians fleeing Uganda and Chileans in the early 1970s as well as with Indochinese boat people later in the decade.

\section{The UN Refugee Convention Is Out of Date}

We did not expect to become a significant country of first asylum since our geographic location made it unlikely that we would be the first available country of refuge for someone fleeing a regime that had been persecuting them. We nevertheless had doubts about whether the provisions of the 1951 Convention would provide suitable terms of reference for Canadian refugee policy and did not, in the event, accede to it until 1969-by which time Canada had become so firmly committed to multilateral solutions to international problems that we found it increasingly difficult not to sign on.

As events were to show, our reservations about acceding to the Convention turned out to be justified. Article 33 stipulated that contracting states could not engage in "refoulement," i.e. expelling or returning refugees to territories where their life or freedom would be threatened on account of their race, religion, nationality, membership of a particular social group or political opinion. This article of the Convention was designed to protect individuals who were fleeing across borders from repressive regimes from being forced back to where they came from-individuals, in effect, whose only chance to reach freedom was to take the route they did. Since Canada had no common borders with countries that persecuted its citizens, it did not seem likely that this provision would come into play very often in our case.

It did so only occasionally as, for example, during the Cold War when the Aeroflot flight from Moscow to Havana stopped in Gander, Newfoundland, to refuel, and passengers from Communist countries sometimes took the opportunity to claim refugee status in Canada. The prospect of large numbers being able to claim asylum in Canada under this provision, however, seemed remote. Most international flights into Canada departed from democratic countries where asylum seekers could apply for refugee status and where they were expected to do so according to generally accepted international rules. To continue on to make a claim somewhere else is considered "asylum shopping" because it involves trying to get to the countries that offer the most generous benefits. Such action indicates that the individual is more concerned about getting to a place where they can enjoy a better life than they are about reaching safety since they chose not to make a claim in the first safe country they managed to reach.

\section{Use of Human Smugglers by Asylum Seekers}

In recent decades, nevertheless, asylum seekers have increasingly made use of the section of the Convention that makes it possible to claim refugee status on our territory and human smugglers have been active in facilitating their movement. According to the RCMP, between 1997 and 2002, smugglers assisted almost 12 per cent of the 14,792 improperly documented migrants who were intercepted in Canada or en route. ${ }^{8}$ This presumably referred to cases that had been clearly identified as involving human smugglers and the real percentage may be much higher. One RCMP officer as well as some immigration department officials reportedly estimated that as many as 90 per cent of refugee claimants accepted by Canada between 1983 and 1995 got here with the assistance of human smugglers. ${ }^{9}$

One reason why the use of smugglers has become so widespread is very likely the fact that migrants attempting to enter countries without the proper authorization have had to resort to professional help to get around the increasingly sophisticated control measures of governments. The imposition of visitor visas, introduction of documents that are difficult to counterfeit, and presence of control officers at airports have reduced the ability of amateurs to bypass controls and, thereby, increased the use of human smugglers with more professional skills and knowledge.

Canada's popularity as a destination for asylum seekers is borne out by the number of claims made in this country compared to those made elsewhere. In recent years, for example, Canada has had by far the largest number of asylum claims among the G8 major industrialized nations on a per capita basis even though we are the most difficult to reach because of our geographic location. ${ }^{10}$

Our popularity is due to a combination of factors that include our high rates of acceptance, our readiness to consider claims from citizens of any country in the world, our generous package of benefits, and the prospect that, even if one's claim is turned down, the appeals and reviews available make it possible to stay in Canada for years and even decades, with a very good chance of never being made to leave.

\section{The Charter of Rights and the Singh Decision}

The long process often involved in arriving at the final disposition of a claim has been complicated in particular by a decision of the Supreme Court in 1985 (known as the Singh decision) that allowed refugee claimants to receive the full benefit of Section 7 of the Canadian Charter of Rights and Freedoms. Section 7 states, "Everyone has the right to life, liberty and security of the person and the right not to be deprived thereof except in accordance with the principles of fundamental justice." 
This decision has played a major role in making it very difficult for our refugee determination system to deal expeditiously with the large volume of people who make refugee claims in Canada. A former deputy minister of immigration, John L. Manion, warned when the Charter was still in draft that Section 7 should apply only to Canadian citizens (or at least those with legal resident status in Canada) rather than to "everyone," as otherwise it would grant rights to foreigners that would allow them to bypass or frustrate our immigration laws. ${ }^{11}$

As it turned out, Manion's advice was ignored and the use of the term "everyone" in this section of the Charter made possible the 1985 decision which, in his words, "destroyed any real immigration control, and made Canada the laughing stock of the world, and the destination of too many footloose criminals, terrorists and social parasites." In terms of the number of applications, it is worth noting that in the six years prior to the Singh decision, 42,000 made refugee claims in Canada, while in the six years following the decision this number had ballooned to over 200,000, with close to three quarters of a million being made since 1985 . While this matched to a considerable degree increases in the number of claims made in other Western countries, the Singh decision limited the scope of the Government's response and made Canada a more attractive destination for asylum shoppers.

In a letter written in 1999 to the then minister of citizenship and immigration, Manion recommended that the Government use the "notwithstanding" clause of the Charter to address the problems created by the Singh decision in terms of extending Charter rights to anyone seeking to remain in Canada. In Manion's judgment, as a sovereign country, Canada must be in a position to make summary decisions in cases of those who have no legal connection to this country, as virtually every other country in the world does.

Manion, however, was not sanguine about the likelihood of the Government invoking the "notwithstanding" clause for this purpose and, therefore, proposed at the very least that Canada formally cancel its accession to the UN Convention. In his view, Canada was very generous in the way it dealt with people fleeing from persecution in repressive countries and should continue with this tradition. By the same token, we should not be subject to international rules that were no longer relevant to current realities and should be free to develop our own policies for dealing with such situations as we saw fit.

\section{Criticism of the Refugee Convention}

Manion has not been alone in criticizing the Convention. In 2001, British Home Secretary Jack Straw called for the redrafting of international refugee rules because "people traffickers" were effectively deciding who was coming to Britain and claiming refugee status. In 2000, Australian Immigration Minister Phillip Ruddock warned that the 1951 Convention was out of date and being manipulated by people who were not genuine refugees. A paper prepared by the Australian Parliamentary Library provides one of the most comprehensive critiques of the Convention, noting that is "anachronistic" and "developed in and for a different era.” It observes, "While Western countries' asylum systems might have coped well enough until the end of the Cold War, they were not designed with today's mass refugee outflows and migratory movements in mind.” Former British Prime Minister Tony Blair made similar observations in his memoirs published in September, 2009. In Blair's view, the Convention, written in response to the horrors of World War II, had helped create a system that was completely unrealistic in today's world and utterly incapable of dealing with the massive number of asylum claims now being made. ${ }^{12}$

It is clear that provisions of the 1951 Convention are illsuited to the realities of today's world. While the Convention drafters envisaged relatively small numbers of people fleeing across borders from countries that were persecuting them and were seeking sanctuary in the first safe country they could reach, we now are faced with having tens of thousands of people travelling great distances to reach the country that will give them the greatest benefits. In doing so, many if not most pass through or bypass other countries where they could have sought asylum. In a great many cases they do so with the aid of human smugglers.

Ideally, countries that accept refugees for permanent resettlement could together produce a new convention based on today's realities. Reaching agreement on what should be included would almost certainly prove to be difficult, however, because of the legal frameworks for dealing with asylum seekers that have developed over the years in various countries as well as because of the influential domestic refugee advocacy lobbies that argue for ever more generous provisions for asylum seekers.

\section{Canada Should Consider Withdrawing from the Refugee Convention}

In the circumstances, it would be much more realistic for Canada to withdraw its accession to the UN Convention and create its own framework for dealing with asylum seekers. It could seek to do this in concert with other countries such as Australia that regard themselves primarily as countries of resettlement for refugees rather than of first asylum.

There is no question that were the Government to embark on such a course of action it would face strident opposition from a range of groups that have to date been able to play 
a major role in determining our policy towards asylum refugee claimants. These include immigration lawyers who have built careers around representing clients who are asylum seekers as well as organizations such as the Canadian Council for Refugees and Amnesty International. All frequently remind us that we have no choice but to let virtually anyone who wishes to do so come to Canada and have their refugee claims heard because of our "international obligations" quite apart from the impact the Charter has had on the refugee determination system because of the Singh decision.

In addition to the problems created by the wording of the Charter that made possible the Singh decision and the outdated UN Convention, a particularly serious impediment to the creation of a workable and fair refugee determination system in Canada is our failure to make adequate use of safe third country ${ }^{13}$ provisions in determining who may make refugee claims in Canada.

\section{The Need to Apply the Safe Third Country Principle More Robustly}

The safe third country concept is based on the principle that, if someone flees their country of origin, they should seek sanctuary in the first safe country they are able to reach. If, however, they choose to move on to somewhere else to seek asylum, it indicates that their primary concern was not to reach safety but rather to be allowed to seek asylum and remain permanently in countries where there are generous benefits, high rates of acceptance, etc. In this regard they are considered to be "asylum shoppers."

When the legislation creating the Immigration and Refugee Board was drafted in the late 1980s it was fully intended that that a list of safe third countries would be established in order that Canada not be inundated with asylum shoppers and so that the refugee determination system would be able to process both expeditiously and thoroughly a relatively limited number of claims. In the event, the refugee lobby was sufficiently influential that it was able to convince the then minister of immigration that no other country in the world but Canada was safe for asylum seekers and none should, therefore, be designated as safe third countries (James Bissett has described in some detail how this came about $\left.^{14}\right)$.

Since these events took place, Canada has concluded a Safe Third Country Agreement (STCA) with the United States under which asylum seekers must seek protection in the first of the two countries where they have an opportunity to do so, rather than, as in the past, being able to go to the mutual border and apply for refugee status in the other country. While this has led to complaints from refugee activists who argue that the United States is far too parsimonious ${ }^{15}$ when it comes to granting asylum, significant numbers of refugee claimants are still able to enter Canada at the US border if they qualify under one of the exceptions to the agreement.

Very clearly a key element in our being able to keep access to the refugee determination system to a manageable level is we must make more extensive use of the safe third country principle as do other Western countries. It makes no sense for us to cater to asylum shoppers who have arrived here via Britain, France, or other democratic countries that have good human rights records. This does not mean that some of them may not have a good case for claiming refugee status or that they should be prevented from making claims but simply that they must return to the safe country they travelled through en route to Canada to make their claims.

The Immigration and Refugee Protection Act stipulates that one of the factors to be considered in designating a country as a safe third is whether it is party to an agreement with Canada for the purpose of sharing responsibility with respect to claims for refugee protection. Since IRPA only states that such an agreement will be a "consideration" rather than a mandatory requirement, we should be able to designate appropriate countries as safe thirds without having to seek their concurrence. Should it be determined that the wording of IRPA means that having an agreement with another state is mandatory before it can be designated as a safe third, the legislation should be amended to remove such a requirement. We should also review the exceptions to the STCA with the United States since some of these are of questionable merit and should be eliminated.

\section{The Refugee Determination System Requires a Complete Overhaul}

The foregoing proposals do not constitute a comprehensive list of the measures needed to correct a refugee system that has become highly dysfunctional over the years. In a paper published recently by the Frontier Centre for Public Policy, former Canadian ambassador and executive director of the Canadian Immigration Service, James Bissett, makes the point that half measures will not work and fundamental changes have to be put in place. ${ }^{16}$ The same message was conveyed in the Auditor General's report in 1997 that detailed a wide range of problems with the system and cautioning against attempts at patchwork modifications. ${ }^{17}$ There has, in the event, been little improvement since the report was released.

One of the most important changes that must be made to the system is to put in place measures that will discourage individuals from making refugee claims in Canada if they have an opportunity to seek asylum in other safe countries or else apply from abroad to come here as refugees. We 
would then once again be able to concentrate our efforts on resettling refugees from overseas. We do, after all, resettle more than 10,000 a year who apply from overseas and there are currently 42,000 waiting patiently in line to come to Canada through this channel. ${ }^{18}$ Why, therefore, should we give preference to those who have the resources to pay human smugglers in order to jump this queue? It can hardly be argued that coming to Canada constitutes their only chance to escape persecution when most of them could have sought asylum in countries much easier to reach.

\section{Our System Is Extremely Costly and Unfair to Refugees Overseas}

The current system is inequitable to those in need of protection in other ways as well. The cost to Canadians taxpayers of failed claimants alone is estimated to be in excess of $\$ 1$ billion a year-or $\$ 50,000$ each. ${ }^{19}$ At the same time, however, Canada contributed only $\$ 45$ million in 2009 to the UNHCR for the protection and assistance of the ten million refugees under its care overseas-which amounts to about $\$ 4$ each. Surely our priorities are skewed when this is allowed to happen.

A further possibility that should be considered to bring more order to the system is the imposition of an annual ceiling on how many refugees we accept each year. Originally, we operated on an ad hoc basis; we accepted people as a particular crisis developed overseas-as was the case with the Hungarians, the Czechs, and subsequent refugee movements. In order, presumably, to accommodate the planning of non-governmental organizations assisting in the resettlement of refugees, we established annual targets.

\section{We Need to Establish an Annual Limit on the Number of Refugees Accepted in Canada}

We now, however, also have large flows of self-selected refugee claimants arriving in Canada (a situation we did not anticipate in earlier days) in addition to both annual targets for resettlement and, on occasion, ad hoc responses to particular situations overseas-such as our agreement to accept 5,000 refugees from Bhutan in 2007. In the circumstances, it would make sense to establish annual limits for the combined totals entering through all of these channels. Canada is, after all, one of the most generous countries in the world when it comes to the acceptance of refugees from overseas and, in order to maintain public confidence in the system, we should deal with overall numbers in a more orderly fashion.

Australia, by way of example, establishes the number of refugees it will take each year and this includes those resettled from overseas as well as those accepted who have made claims onshore. ${ }^{20}$ The Australian total in recent years has ranged between 13,000 and 14,000. If larger numbers than expected come in through one channel, they are reduced in other areas to keep the overall intake within the established limits.

In Canada's case, while there is widespread public support for taking in a reasonable number of genuine refugees, this would be better served if the numbers of successful refugee claimants who applied in Canada were combined with those resettled from abroad to produce an annual total.

\section{Conclusions}

Changing the way in which Canada deals with people who arrive on our territory and make refugee claims is both complicated and controversial and there is clearly a lack of public confidence in the present system. It is open to widespread abuse, unfair to genuine refugees waiting to come to Canada, extremely costly, and constrained by domestic and international legal obligations that are ill-fitted to current realities. It is also an area of concern in relation to protecting and preserving our sovereignty since we currently have limited control over who enters and remains on our territory if they claim refugee status.

Correcting the problems related to the refugee determination system poses an immense challenge to any government given the array of individuals and organizations that oppose virtually every attempt to reform it that involves restricting access or reducing opportunities for failed claimants to prolong their stay in Canada. As noted above, some of the principal impediments to making fundamental improvements to the system include the 1985 Singh decision based on Section 7 of the Charter of Rights and Freedoms, the 1951 United Nations Convention relating to the Status of Refugees, and our failure to establish an adequate list of safe third countries.

While there remains strong support in Canada for accepting genuine refugees, it is equally clear that most Canadian believe that the current system is not working properly and needs a major overhaul. ${ }^{21}$ The numbers of people attempting to enter Canada by any means available is only likely to increase in the future. The International Organization for Migration (IOM) estimates that in 2010 there were 214 million international migrants and that at the current rate of growth this could reach 405 million by $2050 .^{22}$

While many of these migrants will be crossing borders legally, in its report the IOM expresses concern over the emerging patterns of irregular migration involving inter alia asylum seekers. It states that:

Current and future challenges of irregular migration result not only from increasing numbers. Irregular migration is also 
becoming more complex, not just because of the variety of routes into irregularity, but also because of the difficulties in distinguishing the particular needs and rights of various types of persons forming part of irregular migration flows-for example, asylumseekers or unaccompanied minors ... Fundamentally, irregular migration should be curbed because it undermines the rule of law and exerts a heavy human toll on the migrants themselves. When destination countries tolerate high levels of irregular migration, they undermine their own legal immigration systems. There is little credibility for immigration law if migrants and migrant smugglers and human traffickers are allowed to circumvent the policies in place to determine who enters, for what purposes, and for what period of time. Irregular migration also undermines public support for immigration. Often, the public reacts negatively to migration because it feels that the government no longer has control over who is to be admitted. High levels of irregular migration can thus create a backlash that extends to legal immigration as well. ${ }^{23}$

In the circumstances, Canada should put its house in order sooner rather than later and take steps to ensure that, while continuing to accept a reasonable number of genuine refugees for resettlement, these should come essentially from among those who have been selected abroad and few from the ranks of those who make refugee claims in Canada.

Political parties that fail to recognize this state of affairs can eventually expect to pay a price in terms of support at the ballot box.

\section{Notes}

1. UNHCR, Statistical Yearbook 2008, Table 12.

2. Judy Sgro, who was one of the Liberal Government immigration ministers who refused to implement the RAD, was quoted in July 2004 as stating that there were already too many appeals available to failed refugee claimants that enabled them to delay their departure from Canada; Jim Bronskill, "Refugee Appeals Too Slow, Too Costly, Sgro Says," Globe and Mail (Toronto), July 27, 2004.

3. James Bissett, "Abusing Canada's Generosity and Ignoring Genuine Refugees," Frontier Centre for Public Policy, October 2010, 44, accessed November 15, 2010, http:// www.fcpp.org/files/1/PS96_Refugees_NV02F2.pdf.

4. Brian Lilley, "Send Tamil Migrants Home: Poll," Toronto Sun, August 20, 2010, accessed November 15, 2010, http:// www.torontosun.com/news/canada/2010/08/19/15080536 .html.

5. Angus Reid Canadian Public Opinion Poll, "More Canadians Are Questioning the Benefits of Immigration," September 9, 2010, accessed November 15, 2010, http://www.visioncritical.com/wp-content/uploads /2010/09/2010.09.09_Immigration_CAN.pdf.

6. A Maclean's magazine article reported in1996 that "According to records from the consular section of the Sri Lankan
High Commission, more than 8,600 Sri Lankans with refugee claims pending in Canada applied for travel documents to visit Canada in 1992. The following year, the figure was 5,865"; see Paul Kaihla, "A Divided Community," Maclean's, April 29, 1996, 23. More recently, a government document obtained through access to information showed that over 70 per cent of successful Tamil refugee claimants surveyed returned to Sri Lanka for vacations, business, or to sponsor family members; see Brian Lilley, "Refugees Go Home for Holidays," Toronto Sun, August 22, 2010, accessed November 16, 2010, http:// www.torontosun.com/news/canada/2010/08/21/15098916 .html? comments_page $=14 \&$ id $=15098916$.

7. OECD, “Trends in International Migration 2001," 23, Box 1.2., accessed November 16, 2010, http://books.google. $\mathrm{ca} /$ books? id=fmzet910itsC\&pg=PA23\&lpg=PA23\&dq= kosovar+refugees $+i n+$ Germany\&source $=$ bl\&ots $=$ BZA4aERJE9\&sig=PeZWVa0HYepUaBAxQ2B4H2x9 t9A\&hl=en\&ei $=$ fwLOTNH4C4iisAOL37yWDg\&sa= $\mathrm{X} \&$ oi=book_result $\& \mathrm{ct}=$ result $\&$ resnum $=10 \& \mathrm{ved}=$ 0CDsQ6AEwCQ\#v=onepage\&q=kosovar\%20refugees $\% 20$ in $\% 20$ Germany\&f=false.

8. RCMP, "The W-5 of Human Smuggling to Canada," October 2006, accessed November 16, 2010, http://www .rcmp-grc.gc.ca/imm-passp/hum-smuggling-clandestin -eng.pdf.

9. Paul Kaihla, "The People Smugglers," 18.

10. OECD, "2010 International Migration Outlook Statistical Annex, A.1.3 Inflow of Asylum Seekers into Selected OECD Countries," accessed November 16, 2010, http://www.oecd.org/document/57/0,3343,en_2649 _39023663_45634233_1_1_1_1,00.html.

11. John L. Manion, unpublished letter to Minister of Citizenship and Immigration Elinor Caplan, August 11, 1999. Manion also spoke about the impact of the Singh decision on the refugee determination system when he testified before Standing Senate Committee on Social Affairs, Science and Technology on October 3, 2002.

12. Tony Blair, A Journey: My Political Life (New York: Alfred A. Knopf, 2010), 204-05.

13. The term "safe third country" refers to a country that an asylum seeker has passed through and where they could have made a claim but chose instead to continue their journey in order to seek asylum somewhere else.

14. Bissett, "Abusing Canada’s Generosity," 20, 21.

15. Refugee activists argue that US asylum provisions are less generous than Canadian on the basis that their acceptance rates are lower and for various other reasons. Prior to the inception of the STCA, however, it was more common for Canadian activists to claim that our provisions were tougher than those of the United States in an effort to rebut those who claimed that Canada was too soft on refugee claimants. Because the two systems differ in many respects, it is not difficult to find points that support both arguments if one chooses to be selective. 
16. Bissett, "Abusing Canada's Generosity," 41 and 43. In addition to Bissett's paper, comprehensive critiques of the refugee determination system have been written by Charles M. Campbell, Betrayal and Deceit: The Politics of Canadian Immigration (West Vancouver, BC: Jasmine Books, 2000); Daniel Stoffman, Who Gets In? What's Wrong with Canada's Immigration Program and How to Fix It (Toronto: Macfarlane, Walter \& Ross, 2002); Stephen Gallagher, Canada's Dysfunctional Refugee System, The Fraser Institute, 2003, accessed December 10, 2010, http://www .fraserinstitute.org/research-news/display.aspx?id=12865; and Martin Collacott, Canada's Inadequate Response to Terrorism: The Need for Policy Reform, The Fraser Institute, 2006, accessed December 10, 2010, http://www.fraserinstitute .org/research-news/display.aspx?id=12868.

17. Auditor General of Canada, "Citizenship and Immigration Canada and Immigration and Refugee Board: The Processing of Refugee Claims," Section 25.146, 1997, accessed November 25, 2010, http://www.oag-bvg.gc.ca/internet/ English/parl_oag_199712_25_e_8111.html.

18 Public Safety Canada, "Canada’s Generous Program for Refugee Resettlement Is Undermined by Human Smugglers Who Abuse Canada's Immigration System" October 21, 2010, accessed November 25, 2010, http://www.publicsafety .gc.ca/media/nr/2010/nr20101021-6-eng.aspx.

19. Jason Kenney, "Speaking Notes: Balanced Refugee Reform," March 30, 2010, accessed December 8, 2010,
http://www.cic.gc.ca/English/department/media/ speeches/2010/2010-03-30.asp\#tphpidtphp.

20. Department of Immigration and Citizenship, "Fact Sheet 60-Australia's Refugee and Humanitarian Program," accessed November 25, 2010, http://www.immi.gov.au/ media/fact-sheets/60refugee.htm.

21. A survey carried out by Harris/Decima found that 84 per cent of Canadians agree that the Government should take steps to reform the refugee determination system; see Citizenship and Immigration Canada, Refugee Omnibus Report September 2009 Executive Summary, 6.

22. International Organization for Migration, "World Migration Report 2010," November 26, 2010, xix, accessed December 10, 2010, http://publications.iom.int/bookstore/ free/WMR_2010_ENGLISH.pdf.

23. Ibid., 30.

Martin Collacott served as ambassador of Canada to countries in Asia and the Middle East. He has written and spoken extensively on issues related to the refugee determination system and is currently a senior fellow at the Fraser Institute and spokesperson for the Centre for Immigration Policy Reform. 